The imagination grows more borrified with that which is supplied for its food and stimulant. The little ones are told that devils will be continually friglitening them, Death staring at them; the vain will have to wear bonnets and dresses of the hottest fire of Hell, which burns everything for ever, and never burns anything away. A poor girl who loved dancing in the world implores Satan to let her little brothers and sisters know what has come of it; but, of course, Satan will not help her. The children of of earth are even bidden to look into the horrible gulf to behold their fathers tossing in it helplessly; others are shown whole families, the members of which are tearing each other to pieces; which are renewed, to be again torn, each accusing the other of the calamity which has overwhelmed all. In short, within a few pages are enumerated borrors which defy all description. Almost universal empire is ascribed to Satan; all power over men is ascribed to him; the might, majesty, the love, the very will of God are burnt out by the all-devouring flames of Eternal Hall; and Christ is depicted as rather querulously stating that he had done his atmost to save mankind, but that the Devil, after all, had by far the best of it!

We add no word to this illustration. Judgment is free. We will only say that in all the myths of the Middle Ages, there is not one so utterly astounding, 80 horrible, 80 repulsive, and so mendacious as the myths of the present time depicted by Mr. Furniss, permissu superiorum.-The Alhencum.

\title{
Pavilion Asylums.
}

In a paper which he read before the Medico-Psychological Association, and has now reprinted from the 'Juurnal of Mental Science,' Dr. Lockhart Robertson advocates the application of the pavilion system of construction, as exemplified in the Herbert Hospital at Woolwich, to the building of public asylums for the insane. We cun readily conceive that there might be some great advantages in breaking up a large asylum into separate pavilions, connected by suitable corridors, and under one administration. The best ventilation would, at any rate, be obtained; and it might be desirable, for other reasons, to do away with the congregation under one roof of so many lunatics. Facilities would be presented for a complete classification of the patients according to the nature of their disease, their bodily condition, and the probabilty of recovery. The system contains within itself the means of an easy and inexpensive extension, in case of an increase of accommodation being found necessary; and there seems no reason to think that the efficacy of the administration would be at all interfered with. Dr. Robertson appends to his paper the plan of a pavilion asylum for 250 patients, with easy means of enlargement for 400 or 550 ; and claims for it the merit of economy. Though there may be reasonable doubt of this in some minds, the pavilion system of construction certainly seems to offer undoubted advantages over the modification of the prison system which is in fashion, and may fairly claim a trial, should it be found necessary, to add another to the numerous large asylums scattered over the country.-British Medical Journal. 